Proc. Indian Acad. Sci. (Earth Planet. Sci.), Vol. 90, No. 3, November 1981, pp. 227-235. CPrinted in India.

\title{
Radiometric age of the snout ice of Nehnar glacier
}

\author{
N BHANDARJ, D I BHATT, V N NIJAMPURKAR, \\ R K SINGH*, D SRIVATSAVA* and C P VOHRA* \\ Physical Research Laboratory, Ahmedabad 380009 , India \\ *Glaciology Division, Geological Survey of India, Lucknow 226007 , India
}

MS received 25 May 1981 ; revised 11 September 1981

\begin{abstract}
The surface ice taken from the snout of the Nehnar glacier (Kashmir) in western Himalaya has been dated using radioisotopes $32 \mathrm{Si}$ and $210 \mathrm{~Pb}$ to be 500 years. Based on the age distribution of ice and the expected activity of $32 \mathrm{Si}$ in the fallout, the average rate of glacier movement over a period of the last few centuries is estimated to be about $6 \mathrm{~m} / \mathrm{yr}$.

The data obtained on $32 \mathrm{Si}$ and $210 \mathrm{~Pb}$ activities in the surface ice samples in the ablation zone support our previous observation about the existence of five zones of alternately high and low activity of $210 \mathrm{~Pb}$, which probably is a consequence of complex dynamics of Nehnar glacier.

The vertical profile of $210 \mathrm{~Pb}$ activity in an ice core correlates directly with the total beta activity. This radioactive horizon at an altitude of $4140 \mathrm{~m}$ appears to be located at a depth of $10-12 \mathrm{~m}$, which is lower compared to the $2-3 \mathrm{~m}$ observed earlier at an altitude of $4150 \mathrm{~m}$.
\end{abstract}

Keywords. Snout ice ; radiometric age ; ablation zone.

\section{Introduction}

Nehnar, a small (about $3.5 \mathrm{~km}$ long and $0.35 \mathrm{~km}$ wide) valley type glacier situated in Panjtarni basin $\left(34^{\circ} 09^{\prime} 30^{\prime \prime} \mathrm{N}, 75^{\circ} 31^{\prime} \mathrm{E}\right.$ ) of Kashmir region in the Western Himalayas, has been extensively studied in the past decade for its surface dynamics and mass-balance (Vohra et al 1975, 76). The annual rates of movement so obtained have been compared with the results of the ${ }^{32} \mathrm{Si}$ and ${ }^{210 \mathrm{~Pb}}$ dating methods to understand the long term behaviour of the glacier in the past (Nijampurkar et al 1982).

With a view to check the earlier results on the rate of glacier movement, its age and surface dynamics, we have collected surface and ice core samples in the ablation zone of Nehnar glacier in 1978 for the second year in succession. The geographical, geological and geomorphological information, sampling techniques, radiochemical procedures and the methods of radioactive assay have been discussed in detail earlier (Nijampurkar et al 1982; Nijampurkar 1974). 
Meanwhile better estimates of the fallout and half life of ${ }^{32} \mathrm{Si}$ have become available (Elmore et al 1980; Kutschera et al 1980) warranting a revision of the earlier data. The fallout value of $32 \mathrm{Si}$ has been estimated from our work in other Himalayan glaciers. Using this information, the age of ice at various locations has been calculated. Implications of these results are discussed here in terms of glacier dynamics in the past.

\section{Sampling details and experimental procedures}

Three surface samples (nominally 2 tons) from the ablation zone of the glacier were collected and analysed for ${ }^{32} \mathrm{Si}$ and $210 \mathrm{~Pb}$ activities, following the procedures described by Nijampurkar et al (1982) and Nijampurkar (1974). Briefly ${ }^{32} \mathrm{Si}$ was counted via its daughter ${ }^{32} \mathrm{P}$ and ${ }^{210} \mathrm{~Pb}$ via its daughter ${ }^{21} \mathrm{Bi}$. After radiochemical purification, $\mathrm{Mg}_{2} \mathrm{P}_{2} \mathrm{O}_{7}$ and $\mathrm{BiPO}_{4}$ were counted on low background GM counters. The counting efficiency for ${ }^{32} \mathrm{P}$ and ${ }^{210} \mathrm{Bi}$ was $37.5 \%$ and $33 \%$ and the counter backgrounds were $2.8 \mathrm{cph}$ and $8 \mathrm{cph}$ respectively. Both the isotopes were counted for several half-lives and the initial activities were calculated from the decay curves.

In addition, an ice core of about $102 \mathrm{~m}$ length was raised in the ablation zone. Its location is shown in figure 1 . Ten samples collected in $2 \mathrm{~m}$ section up to $20 \mathrm{~m}$ depth were melted, acidified and filled in air-tight plastic bottles. These samples were analysed for $210 \mathrm{~Pb}$, total beta and gamma activity, TDS and concentration of $\mathrm{K}, \mathrm{Na}, \mathrm{Ca}$ and $\mathrm{Mg}$ following the techniques described by Nijampurkar et al (1982).

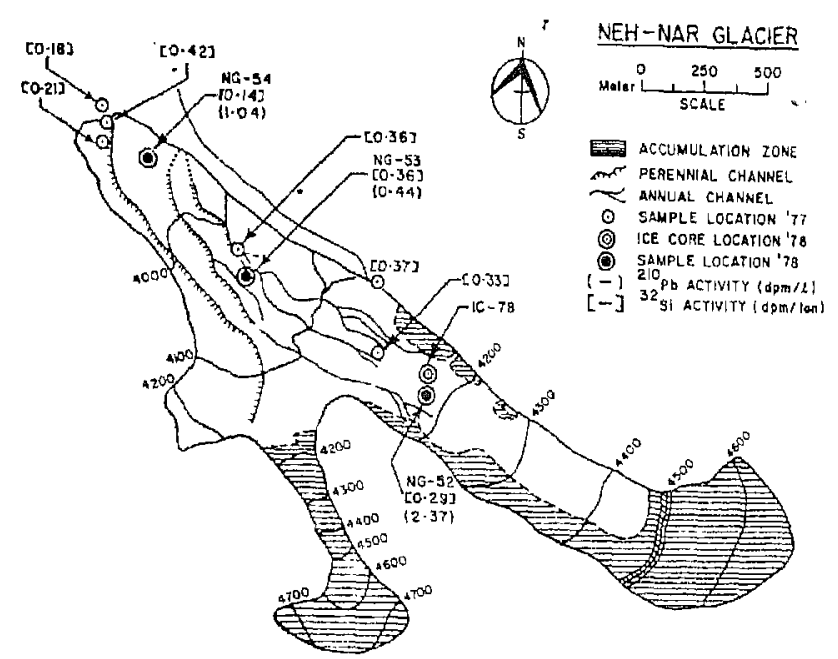

Figure 1. Distribution of $32 \mathrm{Si}$ actrvity [dpm/ton] and $210 \mathrm{~Pb}$ activity [dpm/1] in surface samples of Nehnar gracier. 32Si activity in surface samples collected in 1977 is also given for comparison. Altitude contours [in metres] accumulation zone for 1978 and equilibrium line [dash curve] are shown. The melt and trapped water channels i.e., perennial channels occurring in the lower part of the glacier and annual channels observed in 1978 are also shown. 


\section{Results and discussion}

\subsection{Surface samples}

The ${ }^{3} \mathrm{Si}$ and ${ }^{210} \mathrm{~Pb}$ activities observed in the surface samples are given in tables 1,2 and 3 . The values are in close agreenent with those obtained in the previous year (figure 1). Of particular importance is the ${ }^{32} \mathrm{Si}$ activity in the surface ice of snout sample NG-54 $(0.14 \mathrm{dpm} / \mathrm{ton})$ which represents the oldest ice, except for th: deeper snout samlpes. The ${ }^{210} \mathrm{~Pb}$ activity of the samples NG-52, 53 and 54 are $2 \cdot 37,0.44$ and $1.04 \mathrm{dpm} / 1$ respectively as shown in figure 1 . They agree well with the earlier measurements at these locations. Based on a more detailed work reported earlier, it was possible to identify five zones of alternate high and low activities of $210 \mathrm{~Pb}$ on the glacier, starting from accumulation zone $(4300 \mathrm{~m})$ to snout (Nijampurkar et al 1982). The present data are consistent with the existence of these zones.

The ages of ice can be calculated from the observed ${ }^{32} \mathrm{Si}$ activity based on the decay equation using the half-life of ${ }^{32} \mathrm{Si}$ and its fallout value. Recently the half-life of ${ }^{32} \mathrm{Si}$ has been measured using Tandem Accelerator Mass Spectiometer to be $108 \pm 18$ y by Elmore et al $(1980)$ and $101 \pm 18$ years independently by Kutschera $a_{-}^{16}$ et (1980). This value is much lower than the previously accepted value of $300 \pm 30 \mathrm{y}$ (Jantsch et al 1974; Clausen 1973; Demaster 1980), estimated from nuclear systematics and geophysical arguments. If the recently calculated average value of 105 years is correct then our earlier estimates of ice ages of 850 years have to be revised to lower values.

The second parameter, the average fallout value in the past precipitation, is difficult to estimate. Considering the latitude dependence of fallout values in $0-30^{\circ} \mathrm{N}$ and $30-60^{\circ} \mathrm{N}$ belts, the ${ }^{32} \mathrm{Si}$ value was assumed to be $0.5 \pm 0.1 \mathrm{dpm} / \mathrm{ton}$ (Nijampurkar et al 1982). Recently Nijampurkar et al (1981a) have observed an altitude dependence of $210 \mathrm{~Pb}$ fallout in snow precipitation on the Changmekhangpu glacier. An increase of a factor of about 3 was observed from $4.6 \mathrm{~km}$ to $5.8 \mathrm{~km}$ altitude. This observation suggests the possibility of some altitude dependence of ${ }^{32} \mathrm{Si}$ fallout. Considering the fact that the production profile of ${ }^{210} \mathrm{~Pb}$ and of ${ }^{32} \mathrm{Si}$ in the troposphere is similar, the altitude dependence of the fallout could be assumed to be the same for the two isotopes which is confirmed by measurements of ${ }^{32} \mathrm{Si}$ or any other cosmic ray produced isotope. In a continuously receding glacier like Nehnar, it can be assumed that only the present accumulation zone has been having a positive mass balance. Hence the fallout value is significant in this region only and altitude variation throughout the glacier is not relevant for age calculations. The data recently oblained in Gara, Gorgarrang and Changme-Khangpu glaciers in the Himalaya on ${ }^{32} \mathrm{Si}$ activity in ice in the ablation zones suggest that the fallont value should be about $0.7 \mathrm{dpm} /$ ton (Nijampurkar et al 1981a). The error introduced in the age estimates due to uncertainty in the fallout value is however small. A factor of two error in fallout of ${ }^{210} \mathrm{~Pb}$ and ${ }^{32} \mathrm{Si}$ introduces an error in age of one half life i.e. 22 and 105 years respectively.

In view of the above considerations, we adopt for the purpose of the present calculations. a halflife value of ${ }^{32} \mathrm{Si}$ to be $105 \pm 18$ years and the average fallout 


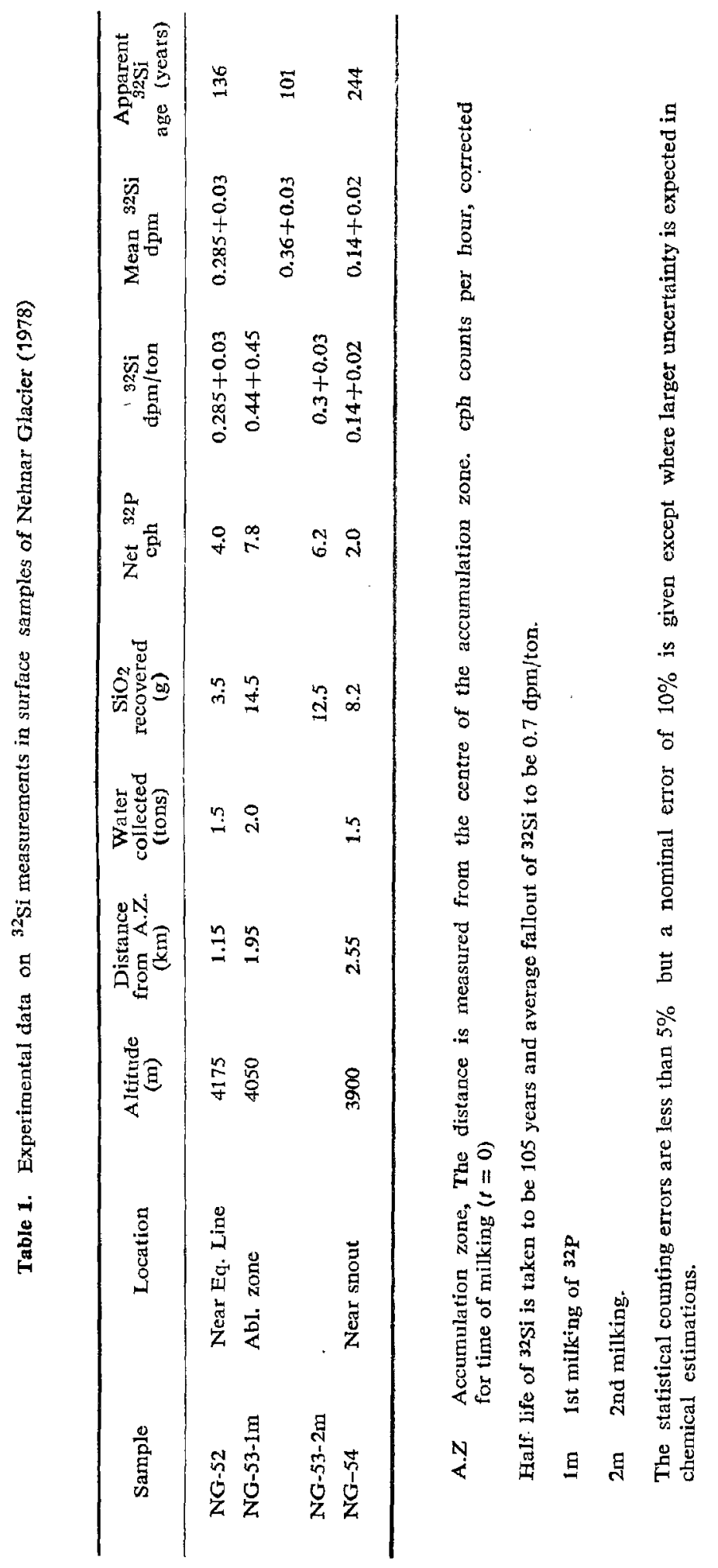



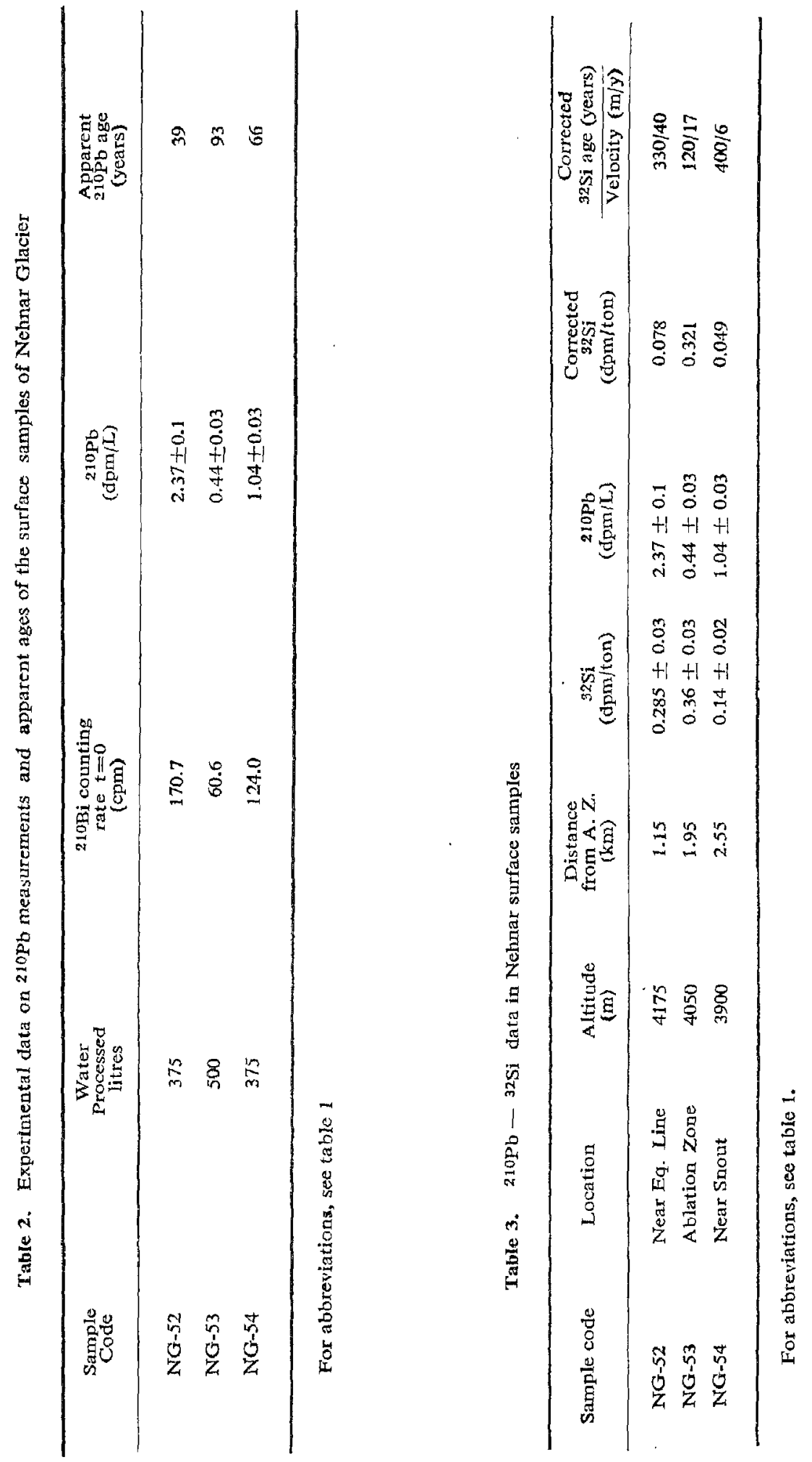
value of ${ }^{32} \mathrm{Si}$ and ${ }^{210} \mathrm{~Pb}$ at an altitude of $5 \mathrm{~km}$ in Himalayas to be $0.7 \mathrm{dpn} / \mathrm{ton}$ and $8 \mathrm{dpm} / 1$ respectively.

As seen from tables 1 and 2 , the apparent ${ }^{32} \mathrm{Si}$ and ${ }^{210} \mathrm{~Pb}$ ages are not concordant. ${ }^{210 \mathrm{~Pb}}$ always yields lower ages indicating some influx of younger ice. We may use a two component model, ${ }^{210} \mathrm{~Pb}$ determining the young component for which corrections can be made to ${ }^{32} \mathrm{Si}$ ages, to obtain true age of the ice (Nijampurkar et al 1982).

Using this approach the model age of ice near the snout of Nehnar glacier is calculated to be 400 years. The sample collected at the tip of the snout during 1977 yields an age of 500-years consistent with the present findings. Similarly the ages of ice at various locations on the glacier are calculated from the observed ${ }^{32} \mathrm{Si}$ and $\{210 \mathrm{~Pb}$ data. Considering that the glacier is $3.5 \mathrm{~km}$ long, the average velocity of the ice movement from acccumulation zone to the snout is estimated to be $6 \mathrm{~m} / \mathrm{y}$. Various ages and velocity estimates are shown in table 3. The high velocity of $17 \mathrm{~m} / \mathrm{y}$ in the middle of ablation zone agrees fairily well with that obtained by Vohra-et al (1976).

\subsection{Ice core samples}

The upper $20 \mathrm{~m}$ section of the core was analysed in every $2 \mathrm{~m}$ depth sections for ${ }^{210} \mathrm{~Pb}$, total beta activity and total dissolved salts. The dust content was measured in the whole core and chemical tracers and stable isotopes $\left({ }^{18} \mathrm{O} /{ }^{16} \mathrm{O}\right)$ were measured in $0-46$ and $66-102 \mathrm{~m}$ sections. Due to a possible contamination of $46-66 \mathrm{~m}$ section by oil used in the drilling operation, this section was not analysed for the chemical and isotopic constituents. Some results are given in table 4 and are summarised below. The ${ }^{18} \mathrm{O} /{ }^{16} \mathrm{O}$ measurements will be reported elsewhere (Nijampurkar and Bhandari 1982).

3.2a. Radioisotopes: The results (given in table 4) show a maxima in ${ }^{210 \mathrm{pb}}$ activity $(33.5 \mathrm{dpm} / 1)$ which is higher by a factor of four compared to its nomal fallout value. This peak correlates with total beta activity $(66.3 \mathrm{dpm} / 1)$ and a. $0.66 \mathrm{MeV}$. $y$ emitter which is tentatively identified as ${ }^{137} \mathrm{Cs}$. Even though the peak values are comparable with those observed in the previous year, maxima appears to be shifted to lower depths at $10-12 \mathrm{~m}$ (figure 2) compared to the depth of 2-3 m observed earlier (Nijampurkar et al 1980.) The location of the 1977 core was $50 \mathrm{~m}$ down slope from the 1978 core location.

Considering the recent work done on Greenland ice shcet cores at Dye-3 station (Nijampurkar et al 1981b), the high $210 \mathrm{~Pb}$ activities observed in this radioactive horizon cannot be solely attributed to the effect of nuclear weapons testing. The suspended dust probably plays a role in contributing some $210 \mathrm{~Pb}$ activity. Verification of its correlation with ${ }^{226} \mathrm{Ra}$ and uranium becomes important for understanding this phenomenon (Jawarowski et al 1978). The garmma analysis of the samples also reveal a marginal signal at $660 \mathrm{keV}$ corresponding to ${ }^{137} \mathrm{Cs}$ (table 4 ), correlating well with $210 \mathrm{~Pb}$ and total beta activity. However since old ice ( $\leq 100$ years based on ${ }^{210} \mathrm{~Pb}$ is observed above this radionctive horizon, special mechanisms have to be invoked to transport the nuclear debris at such 


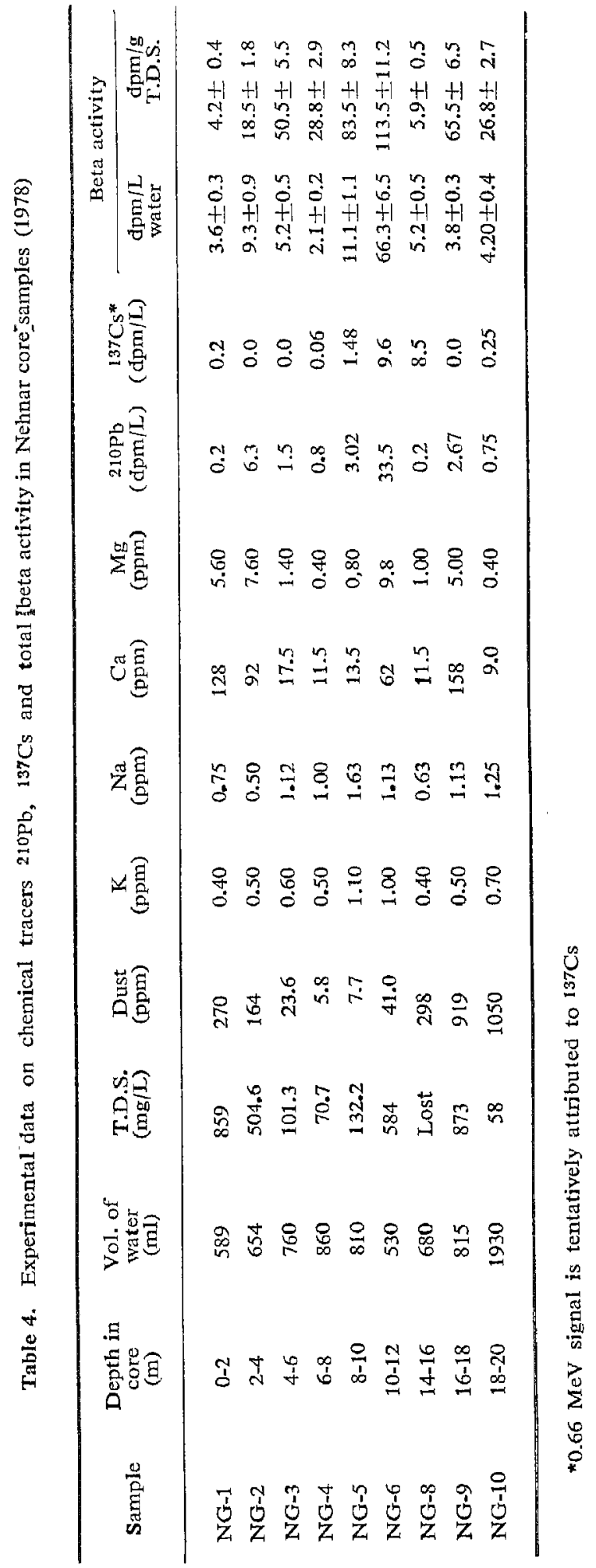




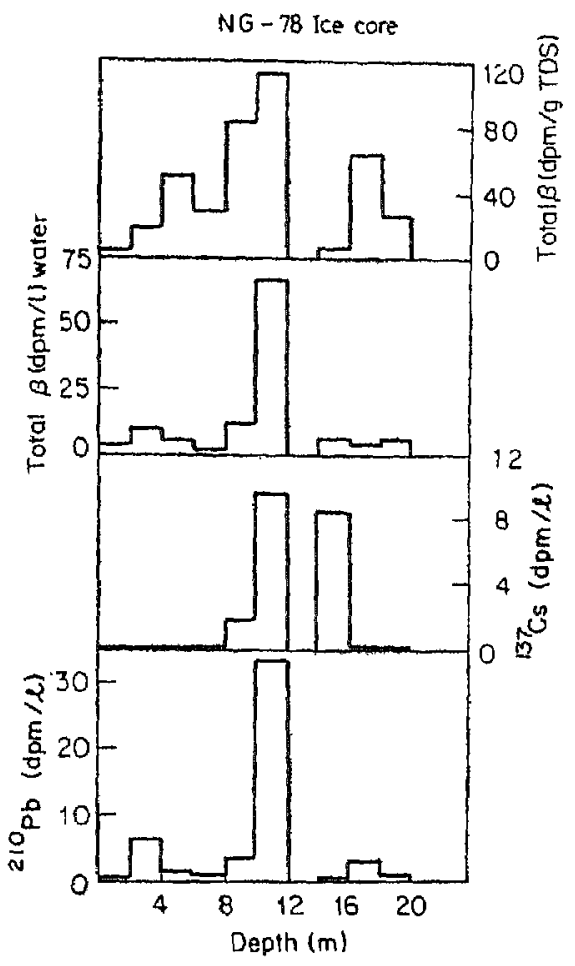

Figure 2. Depth profile of $210 \mathrm{pb}$, and total beta activity [dpm/kg of ice and dpm/g dust] in the Nehnar core samples. The distribution of $0.66 \mathrm{MeV}$ single tentatively attributed to $137 \mathrm{Cs}$ is also shown.

horizons, which is not quite consistent with the present understanding of the glacier dynamics. Thus the conclusion that excess ${ }^{210} \mathrm{~Pb}$ has an origin in nuclear weapons testing must await further analysis of cores, particularly from the accumulation area:

3.2b Chemical tracers: Some major elements, i.e. $\mathrm{K}, \mathrm{Na}, \mathrm{Ca}, \mathrm{Mg}$ were measured, using the atomic absorption spectrophotometry technique, in the melt water samples of core sections taken at $2 \mathrm{~m}$ depth intervals. The suspended dust and TDS were also measured in all these samples (table 4). All major elements correlate with the suspended dust content, as expected. The dust itself varies between 0.1 and $8 \mathrm{~g} /$ litre with three distinct peaks at 33,45 and $61 \mathrm{~m}$ depth. Its correlation with oxygen isotopic ratio will be discussed elsewhere (Nijampurkar and Bhandari 1982; Bhandari et al 1982).

\section{Acknowledgements}

The authors are grateful to Prof D Lal, Physical Research Laboratory, and Shri V S Krishnaswamy, Geological Survey of India, for encouragement in 
continuing this programme. They thank Mr K M Suthar for technical assistance at various stages and several colleagues of GSI, especially to the ice core drilling team for their valuable help and active participation in the field work. The authors appreciate the help of Shri M M Sarin, Shri M R Manchanda and Shri A R Pandyan.

\section{References}

Bhandari N, Nijampurkar V N and Vohra C P 1982 Radiometric chronology of some Himalayan Glaciers Paper presented at the Symposium on variations in the global water budget Oxford

Clausen H $1973 J$. Glaciol. 12411

Demaster D T 1980 Earth Planet Sci. Lett. 48209

Ellmore D, Anantharaman N, Fullbright H W, Gove H F, Hans H S, Nishiizumi K, Murell M T and Honda M 1980 Phys. Rev. Lett. 45589

Jantsch K 1974 Kernreaktionennmit Tritonen beim ${ }^{30} \mathrm{Si}$ : Bestimmung der Halbwertzeit von ${ }^{32}$ Si. Kernenergie, 10, Jahrgang, Hefte 3, 89

Jaworowski Z, Kownaoka $L$ and Bysiek M 1978 Global distribution and sources of uranium, radium-226 and lead-210 Proc. Symp. on natural environment III Houston, April 24-29

Kutschera W, Henning W, Paul M, Snither R K, Stephensen E J, Yntema J L, Alburger D E, Cumming J B and Harbottle G 1980 phys. Rev. Lett. 45592

Nijampurkar V N 1974 Dating of groundwaters by ${ }^{32} \mathrm{Si}$ Ph. D. Thesis, Bombry University

Nijampurkar V N and Bhandari N 1982 Oxygen isotope ratios in Himalayan Glaciers (in preparation)

Nijampurkar V N, Bhandari N, Krishnan V and Vohra C P 1982 J. Glaciol (in press)

Nijampurkar V N, Bhandari N, Borole D V and Bhattacharya U 198 I Radiometric-chronology of the Changme Khangpu Glacier, Sikkim (in preparation)

Nijampurkar V N, Clausen H and Dansgaard W 1981b A century old record of natural fallout of ${ }^{210} \mathrm{pb}$ on Greenland Ice Sheet (in preparation)

Yohra S K, Krishnan V, Pathak C S and Tiwari R A 1975-76 Report on the Panjatarani Glacier expedition, Glaciology dıvision, GSI report, Lucknow 